\title{
Dolerus asper Zaddach, 1859 and Dolerus brevicornis Zaddach, 1859 (Hymenoptera: Tenthredinidae), with notes on their phylogeny
}

\author{
Mikk HEIDEMAA ${ }^{1}$, MAtTI NUORTEVA², JARKKo HANTULA ${ }^{3}$ and URmas SAARMA ${ }^{4}$ \\ ${ }^{1}$ Institute of Zoology and Hydrobiology, University of Tartu, Vanemuise 46, 51014 Tartu, Estonia, and Institute of Plant Protection, \\ Estonian Agricultural University, Viljandi Road, Eerika, 50412 Tartu, Estonia; e-mail: mikk@eau.ee \\ ${ }^{2}$ Alkutie 28D, FIN-00660 Helsinki, Finland \\ ${ }^{3}$ Finnish Forest Research Institute, Vantaa Research Center, P.O. Box 18, FIN-01301 Vantaa, Finland; e-mail: \\ jarkko.hantula@metla.fi \\ ${ }^{4}$ Institute of Zoology and Hydrobiology, University of Tartu, Vanemuise 46, 51014 Tartu, Estonia, and Estonian Biocentre, Riia 23, \\ 51010 Tartu, Estonia; e-mail: urmas.saarma@ut.ee
}

Key words. Hymenoptera, Tenthredinidae, sawfly, Dolerus asper, D. brevicornis, D. derzavini, D. gibbosus, D. harwoodi, taxonomy, neotype, morphology, phylogeny, phenology, molecular markers, distribution

\begin{abstract}
Concordant differences in morphology, phenology and RAMS markers, as well as in sequenced mtDNA (COI, COII, cytb) and nuclear DNA (ITS2) fragments, indicate that Dolerus asper Zaddach, 1859 and Dolerus brevicornis Zaddach, 1859 are valid species. On the basis of morphology, molecular markers, and distributional records, both species are distinct from Dolerus gibbosus Hartig, 1837 (= Dolerus planatus Hartig, 1837). Taxonomy of the species is clarified and the neotypes of Dolerus asper Zaddach, 1859 and Dolerus brevicornis Zaddach, 1859 are designated. The synonymies of Dolerus asper Zaddach, 1859, to Dolerus planatus Hartig, 1837 and Dolerus derzavini Malaise, 1931, spec. rev. to D. asper Zaddach, 1859 are abandoned. Dolerus carbonarius Zaddach, 1859 and Dolerus fumosus Zaddach, 1859 are considered to be species inquirendae. Phylogenetic analyses of the ITS2 fragment and fragments of ITS2 + COI and ITS2 + COII yielded the topology [D. asper, (D. brevicornis, D. gibbosus)], while those of all other markers and their combinations resulted in the topology [D. brevicornis, (D. asper, D. gibbosus)]. In the latter hypothesis the clade asper + gibbosus is also supported by structural synapomorphies.
\end{abstract}

\section{INTRODUCTION}

Dolerus Panzer, 1801 [type species: Tenthredo pedestris Panzer, 1801 by monotypy = Dolerus germanicus (Fabricius, 1775)] is a diverse Holarctic sawfly genus with several taxonomically unresolved species groups. The subgenus Poodolerus Zhelochovtsev, 1988 with about 60 species in the western Palearctic is the most species-rich and taxonomically difficult of this genus. Detailed studies involving the concurrent analyses of morphological, ecological and molecular data can significantly contribute to the recognition of closely related species complexes and the reliable differentiation of their members.

Blank \& Taeger (1992) synonymized Dolerus asper Zaddach, 1859 with Dolerus planatus Hartig, 1837, and included Dolerus brevicornis Zaddach, 1859 in the list of synonyms of D. planatus (Blank \& Taeger, 1998) following the literature (S.M. Blank, pers. comm.). Recently, $D$. planatus was recognized as the male of D. gibbosus Hartig, 1837 (Heidemaa \& Viitasaari, in press). A preliminary study of the males of Dolerus asper auct. from Estonia and Finland by $\mathrm{MH}$ and $\mathrm{MN}$ revealed two morphologically distinct forms based on the structure of the penis valves, form of the clypeus, form of the postocellar furrows, and length of setae on vertex, pronotum and mesepisternum of females. Because these forms are morphologically different from $D$. gibbosus (=D. planatus), we suggest that they are distinct species. To check this, we did a detailed taxonomic study of Dolerus asper auct. incorporating morphometrical, phenological and distributional data as well as molecular markers.

In addition to the taxonomic difficulties concerning $D$. asper auct. nomenclatural problems are involved because the type material of Dolerus species described in Zaddach (1859) is not available. Here we review the taxonomy of Dolerus asper Zaddach, 1859 and Dolerus brevicornis Zaddach, 1859 and designate neotypes. We also discuss the phylogenetic relationships between $D$. asper, $D$. brevicornis and D. gibbosus.

\section{MATERIAL AND METHODS}

\section{Morphological study}

The morphological study is based on material deposited in the following institutional collections:

Department of Applied Biology, University of Helsinki, Finland (DABUH);

Deutsches Entomologisches Institut, Eberswalde, Im LeibnizZentrum für Agrarlandschafts- und Landnutzungsforschung, Germany (DEI, ZALF);

Finnish Museum of Natural History, Helsinki, Finland (ZMH); Institute of Biology, University of Latvia, Salaspils, Latvia (IBUL);

Institute of Plant Protection, Estonian Agricultural University, Tartu, Estonia (IPP);

Museum für Naturkunde der Humboldt-Universität zu Berlin, Bereich Zoologisches Museum, Germany (MNHUB); 
Museum of Zoology, University of Tartu, Tartu, Estonia (MZUT);

The Natural History Museum, London, Great Britain (BMNH);

Naturhistorisches Museum Wien, Vienna, Austria (NHMV);

Naturhistoriska Riksmuseet, Sektionen för Entomologi, Stockholm, Sweden (NHRM);

Zoology Department of the Tromsø Museum, Tromsø, Norway (ZDTM);

Zoological Institute in St. Petersburg, Russia (ZISP);

Zoological Museum, University of Oslo, Oslo, Norway (ZMUO);

Zoologische Staatssammlung München, Munich, Germany (ZSM)

The type material listed below was examined:

Dolerus asper megapteroides Muche, 1964; paratype $q$ (MNHUB);

Dolerus derzavini Malaise, 1931; holotype + (NHRM);

Dolerus docilus Benson, 1956; holotype đ, paratypes 50, 4 ㅇ (BMNH);

Dolerus harwoodi Benson, 1947; holotype ơ, $2 \stackrel{q}{q}$ paratypes (BMNH);

Dolerus oblongus Cameron, 1882; holotype $q(\mathrm{BMNH})$;

Dolerus planatus Hartig, 1837; lectotype ô, $2 \hat{0}$ paralectotypes (ZSM).

In addition, specimens from the private collections of Stephan M. Blank, Manfred Kraus, Jean Lacourt, Jaan Luig, Jouko Nuorteva, Fausto Pesarini, Andreas Taeger, Matti Viitasaari and Veli Vikberg, and the authors MH and MN were studied. Over 1200 specimens of $D$. asper auct. were examined.

Several metrical characters of 20 female and 40 male specimens of $D$. asper auct. were measured using a Wild M8 stereomicroscope with a measuring scale. The measuring units were $0.01 \mathrm{~mm}$ for the penis valve and $0.02 \mathrm{~mm}$ for other characters. Specimens of the two different forms were not measured in groups, but were measured alternately; a specimen of one form was followed by a specimen of another form. Pairwise combination of the measured characters on $\mathrm{x}-\mathrm{y}$ scatter diagrams was used to explore if discrete clusters can be found corresponding to the groups of $D$. asper auct. recognized on the basis of structural characters.

The scanning electron micrographs (SEM) in Figs 6, 8, and 12 were taken in digital format with a JEOL 840 attached to a PC with the computer program SEMAPHORE (version 1.2). The genitalia were processed in $\mathrm{KOH}(10 \%)$ prior to their dissection and study. The Figs 4,7 and $9-11$ are based on micrographs taken with an Olympus Camedia $4040 \mathrm{Z}$ digital camera mounted to an Olympus SZX-9 stereomicroscope. Serrulae of the Dolerus derzavini holotype (Fig. 5) are photographed with a Canon AV-1 camera (film Kodakchrome 25/36) using a Nikon 1.25 microscope (with object-glass: Ph3DL Eplan 40/0.65 160/0.17). Morphological terminology follows Goulet (1986) and Viitasaari (2002). The morphological study was carried out by $\mathrm{MH}$ and $\mathrm{MN}$.

\section{DNA isolation and sequencing}

Insect samples used for DNA sequencing were collected by $\mathrm{MH}$ and US from different localities in Estonia and stored in $96 \%$ ethanol. Both mitochondrial and nuclear markers were analysed. Sequences of the mitochondrial gene fragments of cytochrome $b$ (cytb), cytochrome oxidase subunit I (COI), cytochrome oxidase subunit II (COII) and of the DNA internal transcribed spacer (ITS2) fragments in 3 specimens of the species under study (D. asper, D. brevicornis), as well as in four specimens of $D$. gibbosus and two specimens of D. stygius Förster, 1860 (used as outgroup in phylogenetic study), were deter- mined. DNA was extracted and purified with the QIAamp DNA Mini kit (Qiagen) according to the manufacturers protocol and stored at $-20^{\circ} \mathrm{C}$ until required. The mitochondrial gene fragments were: $c y t b$, amplified with the primers CB-J-10933 (5' TAT GTA CTA CCA TGA GGA CAA ATA TC 3') and TS1N-11683 (5' TAT TTC TTT ATT ATG TTT TCA AAA C 3'); COI, amplified with the primers C1-J-1751 (5' GGA TCA CCT GAT ATA GCA TTC CC 3') and C1-N-2191 (5' CCC GGT AAA ATT AAA ATA TAA ACT TC 3'); COII, amplified the primers TL2-J-3037 (5'ATG GCA GAA AAA TGC AAT GG $3^{\prime}$ ) and C2-N-3661 with 3'-end base omitted (5' CCA CAA ATT TCT GAA CAT TGA CC 3') (Simon et al., 1994). Of the nuclear DNA, the sequence of a ITS2 fragment was amplified using the modified AM1 primer with 2 bases of its $3^{\prime}$ end omitted (5' TGT GAA CTG CAG GAC ACA TGA 3'), and AM2 (5' ATG CTT AAA TTT AGG GGG TAG TC 3') (Marinucci et al., 1999). PCR reactions were carried out in a total volume of $20 \mu \mathrm{l}$ containing 4-100 ng of genomic DNA, 4 pmol of primers, $1.5 \mathrm{mM} \mathrm{MgCl}_{2}, 0.2 \mathrm{mM}$ dNTP mixture, PCR buffer and $1 \mathrm{U}$ of Platinum Taq DNA polymerase (Life Technologies). PCR was performed on Progene Thermal Cycler (Techne), cycling parameters were $5 \mathrm{~min}$ denaturing step at $94^{\circ} \mathrm{C}$, followed by $35-41$ cycles of $1 \mathrm{~min}$ at $94^{\circ} \mathrm{C}, 1 \mathrm{~min}$ at $46-50^{\circ} \mathrm{C}$ depending on a primer set used and $1 \mathrm{~min}$ at $72^{\circ} \mathrm{C}$. PCR product was purified with shrimp alkaline phosphatase/exonuclease I treatment. $1 \mathrm{U}$ of both enzymes (USB) were added to $10 \mu \mathrm{l}$ of PCR reaction and incubated for $27 \mathrm{~min}$ at $37^{\circ} \mathrm{C}$, followed by 15 min at $80^{\circ} \mathrm{C}$. The purified PCR product was directly used for sequencing.

DNA cycle sequencing was performed by using DYEnamic ET Terminator Cycle Sequencing kit (Amersham Biosciences). 33 cycles $\left(15 \mathrm{sec}\right.$ at $95^{\circ} \mathrm{C}, 15 \mathrm{sec}$ at $50^{\circ} \mathrm{C}$ and $60 \mathrm{sec}$ at $\left.60^{\circ} \mathrm{C}\right)$ were performed on Progene Thermal Cycler in a total volume of $10 \mu 1$. To obtain unequivocal sequences, both sense and antisense strands were sequenced, using the same primers as for PCR amplification. Sequences were resolved on an ABI PRISM 377 automated DNA sequencer (Applied Biosystems). Based on the sequences of both strands, a consensus sequence of each marker was created for every specimen. DNA isolation and sequencing were carried out by US.

\section{Multivariate techniques}

In the taxonomic study, multidimensional scaling (MDS) was used for ordination of the similarity matrix representing differences between the analysed samples on the basis of sequence data. The combination of ITS 2 and $c y t b$ sequences was selected, as these markers showed most intraspecific variation. The similarities between the pairs $(\mathrm{x}, \mathrm{y})$ of binary coded sequences were calculated as percent of disagreement (number of $\left.x_{i} \neq y_{i} / i\right)$ using the cluster analysis module, and the ordination was performed using the MDS procedure available in STATISTICA (data analysis software system), version 6 (StatSoft Inc., 2001). The UPGMA dendrogram (Fig. 14) was constructed using the MEGA software package (Kumar et al., 1993).

\section{Phylogenetic analysis}

The sequenced mitochondrial (cytb, COI, COII) and nuclear (ITS2) DNA markers (Table 1) as well as structural characters of the imaginal stage (Table 2) were used to estimate of the phylogenetic relationships. Sequences of the ITS2 fragment were aligned with multiple alignment procedure in Clustal W, which was run in the software package BIOEDIT, version 5.0.9 (Hall, 1999). Sequence data were analysed using the neighbour joining (NJ), unweighted maximum parsimony (MP) and minimum evolution (ME) methods available in the MEGA software package, version 2.1 (Kumar et al., 2001). Phylogenetic analysis using 
morphological data was conducted using the exhaustive search MP procedure in PAUP* 4.0b8 (Swofford, 1998). Molecular and morphological datasets were analysed separately. The mtDNA and nuclear sequences were analysed separately and in all possible combinations. MP analysis was performed using branch-and-bound search with alignment gaps (present in ITS2 only) treated as missing. Support for individual branches was evaluated using the nonparametric bootstrap method with branch-and-bound search and 10,000 pseudoreplicates in all cases. All trees inferred from sequence data were rooted from midpoint. The cladogram resulting from cladistic analysis of morphological data was rooted using $D$. stygius. The phylogenetic analysis was performed independently by MH and US.

\section{Random amplified microsatellite analysis}

Because some females of $D$. asper auct. (under $10 \%$ ) could not be differentiated with confidence using morphological characters, the random amplified microsatellite (RAMS) technique was used to search for suitable markers for their discrimination. The technique is based on primers composed of microsatellite DNA motives and an anchor sequence (Zietkiewicz et al., 1994, Hantula et al., 1996). In RAMS analysis, the DNA between the distal ends of two closely located microsatellites is amplified and the resulting PCR products are separated electrophoretically (Zietkiewicz et al., 1994).

The insect samples for RAMS analysis were collected from Finland (5 $q$ of $D$. brevicornis and $19 D$. asper) and Norway (4⿻ of $D$. asper), and stored in $96 \%$ ethanol. The geographical origin of the samples are: ASP 1 (Nilsiä, Finland); ASP 2, ASP 4 (Boensaeter, Norway); ASP 3 (Vestvatnet, Norway); ASP 5 (Solli, Norway); BRE 1, BRE 3-5 (Nilsiä, Finland); BRE 2 (Hattula, Finland). DNA was isolated by a modification of the method described by Vainio et al. (1997). Tissue from the abdomen of each specimen was transferred to a microcentrifuge tube and disrupted using quartz sand in lysis buffer. Three phenol-chloroform $(1: 1)$ and one chloroform: isoamyl alcohol (24:1) extractions were carried out, and the DNA was precipitated using polyethylene glycol 6000 and $\mathrm{NaCl}$. The pellet was washed with $70 \%$ ethanol, and after drying under a vacuum, the DNA was resuspended into $10 \mathrm{mM}$ Tris- $\mathrm{HCl}$ buffer $(\mathrm{pH} 8.0)$ containing $1 \mathrm{mM}$ EDTA.

The PCR-reactions were carried out in reaction conditions suggested by the manufacturer of Dynazyme II DNApolymerase (Finnzymes Ltd., Finland), except that $2 \mu \mathrm{m}$ of the primer $5^{\prime} \mathrm{DHB}(\mathrm{CGA})_{5}($ where $\mathrm{D}=\mathrm{A} / \mathrm{G} / \mathrm{T}, \mathrm{H}=\mathrm{A} / \mathrm{C} / \mathrm{T}$, and $\mathrm{B}=$ $\mathrm{C} / \mathrm{G} / \mathrm{T}$ ) was used. The samples were denatured by $10 \mathrm{~min}$ incubation at $95^{\circ} \mathrm{C}$ after which 37 cycles of amplification were carried out $\left(30 \mathrm{~s}\right.$ denaturation at $95^{\circ}, 45 \mathrm{~s}$ annealing at $61^{\circ} \mathrm{C}, 2 \mathrm{~min}$ primer extension at $72^{\circ}$ ). After the cycles, the reaction was terminated with a 7 min extension at $72^{\circ}$.

Amplification products were separated by electrophoresis on agarose gels containing 1.0\% SynerGel (Diversified Biotech) and $1.0 \%$ agarose (FMC BioProducts). The electrophoresis was run in TAE-buffer (40 mM Tris-Acetate $\mathrm{pH}$ 8.0, 1 mM EDTA), and the amplification products were visualised using ethidium bromide under UV-light. The lengths of the amplification products were estimated by comparing them to 100 bp DNA ladder (Gibco BRL). Distance matrix was calculated from RAMS markers using Band Sharing Indices calculated according to Lynch (1990). The RAMS analysis was conducted and interpreted by $\mathrm{JH}$.

\section{RESULTS AND DISCUSSION}

\section{Taxonomy and nomenclature of $D$. asper auct.}

If the metrical characters of the specimens of $D$. asper auct., segregated in two morphological groups by structural characters, were represented graphically on $\mathrm{x}-\mathrm{y}$ scatter diagrams, the character combinations resulting in two distinct clusters were found for both sexes (Fig. 1A-B). Two discrete clusters, consisting of ASP 2, ASP 3, ASP 4 and BRE 1, BRE 3, BRE 9, corresponding to the morphologically distinct groups formed if the similarity matrix representing differences between the samples on the basis of their nucleotide sequences was ordinated using nonmetric multidimensional scaling (MDS). To achieve maximal spread of the samples on a scatterplot, the number of calculated dimensions was set on maximum (9). The resulting ordination of the samples in first 2 dimensions is given in Fig. 2. It can be seen that three males (GIB 31, GIB 36, and GIB 37) of the third species, morphologically identical to the lectotype of $D$. planatus, fall in the same cluster with a female (GIB 33) (Fig. 2) that morphologically matches the lectotype of $D$. gibbosus. This confirms that D. planatus is the male of $D$. gibbosus as was suggested earlier on the basis of shared structural characters (Heidemaa \& Viitasaari, in press).

In the two morphological groups detected in $D$. asper auct. the association of females and males, initially based on their shared structural characters, is also supported by molecular markers and corresponding phenological patterns of the sexes. The flight period of both sexes in one group (D. brevicornis) begins and ends earlier than in the other (D. asper) (Fig. 3). Accordance of the variation patterns observed in the different character sets shows that $D$. asper auct. includes two distinct species. Application of the name $D$. asper Zaddach, 1859 has to be fixed by selecting its neotype because the original type material is lost and the description or any other reference information would not ensure unambiguous usage of this name in the present taxonomic situation. Zaddach (1859) emphasized the similarity of the males of $D$. asper and $D$. brevicornis: "Diese Art ist dem D. brevicornis sehr ähnlich ...".

All facts suggest that Zaddach's sawfly collection was destroyed during Word War II and none of the recent sawfly workers have studied the type material of Dolerus species described in Zaddach (1859). According to Horn et al. (1990), the Hymenoptera collection of Gustav Zaddach was partially destroyed during World War II. Preliminary information indicating that the collection was in the Zoological Institute in St. Petersburg (Blank \& Taeger 1998) was later rejected (A. Zinovjev, pers. comm., A. Taeger, pers. comm.). All our efforts to trace the Zaddach's Dolerus types as well as requests sent to several zoological institutions in Lithuania (Vilnius), Germany (Berlin), Poland (Krakow), Russia (Kaliningrad = Königsberg) and Ukraine (Kharkov), were unsuccessful.

Only the female is mentioned in the original description of D. carbonarius Zaddach, 1859. Unfortunately, the additional specimens with the type material referred to in Zaddach (1859) as "Das mir aus dem Berliner entomolo- 

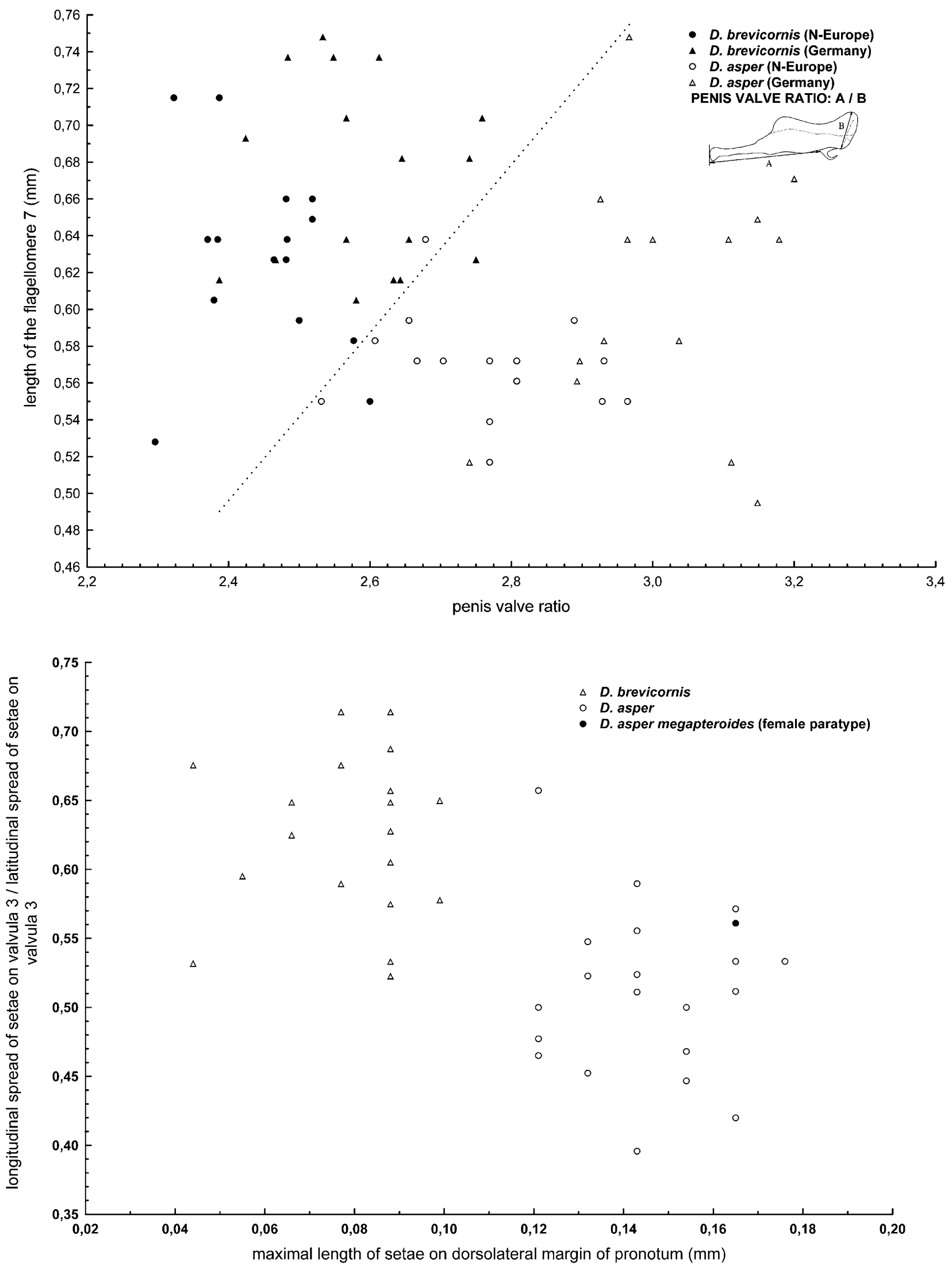

Fig. 1. Relationships of some metrical characters of adults of $D$. asper Zaddach, spec. rev. and D. brevicornis Zaddach, spec. rev. A - males: penis valve ratio (see inset figure) (x) vs length of the flagellomere 7 (y). Dotted line designates the best linear discrimination (misclassification minimised); $\mathrm{B}$ - females: maximum length of setae on dorsolateral margin of pronotum (x) vs longitudinal spread of setae on valvulae 3 / latitudinal spread of setae on valvulae 3 (y). 
gischen Museum zur Ansicht geschickte Weibchen des Dolerus anthracinus gehörte zu dieser Art.", which might help resolve the taxonomic identity of $D$. carbonarius, are not in the Berlin Museum (S.M. Blank, pers. comm.). This species, traditionally listed in the synonymy of $D$. asper Zaddach, 1859, has to be regarded as "species inquirenda". Also, Dolerus fumosus Zaddach, 1859 (preoccupied by Dolerus fumosus Stephens, 1835 = Dolerus zaddachi Kirby, 1882, new name proposed for $D$. fumosus Zaddach) is considered a "species inquirenda" because its type is not available and there is no other information for resolving the identity of this species in present taxonomic context.

For the sake of nomenclatural stability we do not propose any new names but recognize $D$. asper Zaddach, 1859 and D. brevicornis Zaddach, 1859 as distinct species, earlier synonymised to D. planatus Hartig, 1837 (=D. gibbosus Hartig, 1837), and fix the usage of these names by selecting neotypes. This solution is available because the species recognized in $D$. asper auct. match the original descriptions of $D$. asper Zaddach, 1859 and D. brevicornis Zaddach, 1859. In Zaddach's key (Zaddach, 1859, p. 15), the specimens with clearly defined postocellar furrows run to "fissus [valid name: Dolerus nigratus (O. F. Müller, 1776)], carbonarius and brevicornis" while the specimens with obsolete postocellar furrows go to "fumosus and asper". Other characters given

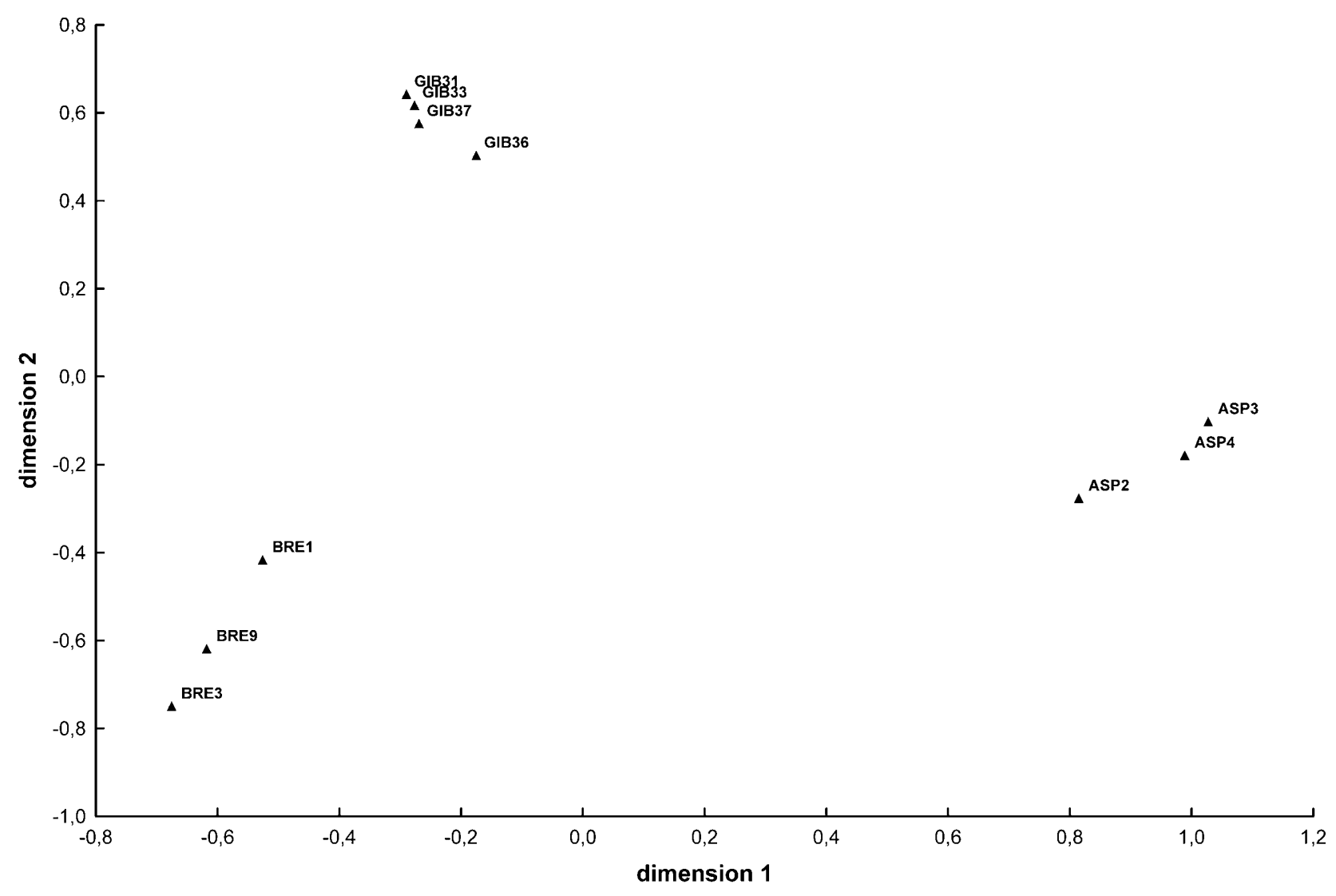

in Zaddach's descriptions, for example the sculpture on tergum I and the relative length of the basal flagellomeres, have no taxonomic value. Because the male of $D$. asper and D. brevicornis are described in Zaddach (1859) and the males of the species recognized in $D$. asper auct. can be determined on the basis of their penis valves, the neotypes selected are males. The short description, are in the female $4.3 \mathrm{~mm}$ and in the male 5 $\mathrm{mm}$. This is not contradictory because the length of the antennae is rather variable and the measurements are not precise.

\section{Morphotaxonomy}

The males of $D$. asper and $D$. brevicornis are most reliably differentiated from each other and from D. docilus Benson, 1956 and D. gibbosus by penis valve structure. $D$. docilus is not conspecific to D. gibbosus as proposed by Lacourt (1999) but a separate species (Heidemaa \& Viitasaari, in press). Its larva is unknown but the adult resembles $D$. asper. The outline of the penis valve of $D$. gibbosus in lateral view resembles that of $D$. asper and D. brevicornis, but the hooklike process at its ventroapical corner is less developed. It is easy to destroy this structure during dissection or if the valves are processed for too long in $\mathrm{KOH}$. In dorsal view, the sharply broadening apical part of the penis in D. gibbosus (Fig. antennae of $D$. brevicornis, according to Zaddach's

Fig. 2. Nonmetric multidimensional scaling ordination of the similarity matrix representing the differences (percent of disagreement) between the samples of $D$. asper Zaddach, spec. rev., D. brevicornis Zaddach, spec. rev., and D. gibbosus Hartig based on the combined binary coded cytb and ITS2 fragments' nucleotide sequences. The first two of the 9 calculated dimensions were used for the ordination of the samples (Final stress $=1.6 \times 10^{-5}$ ). 


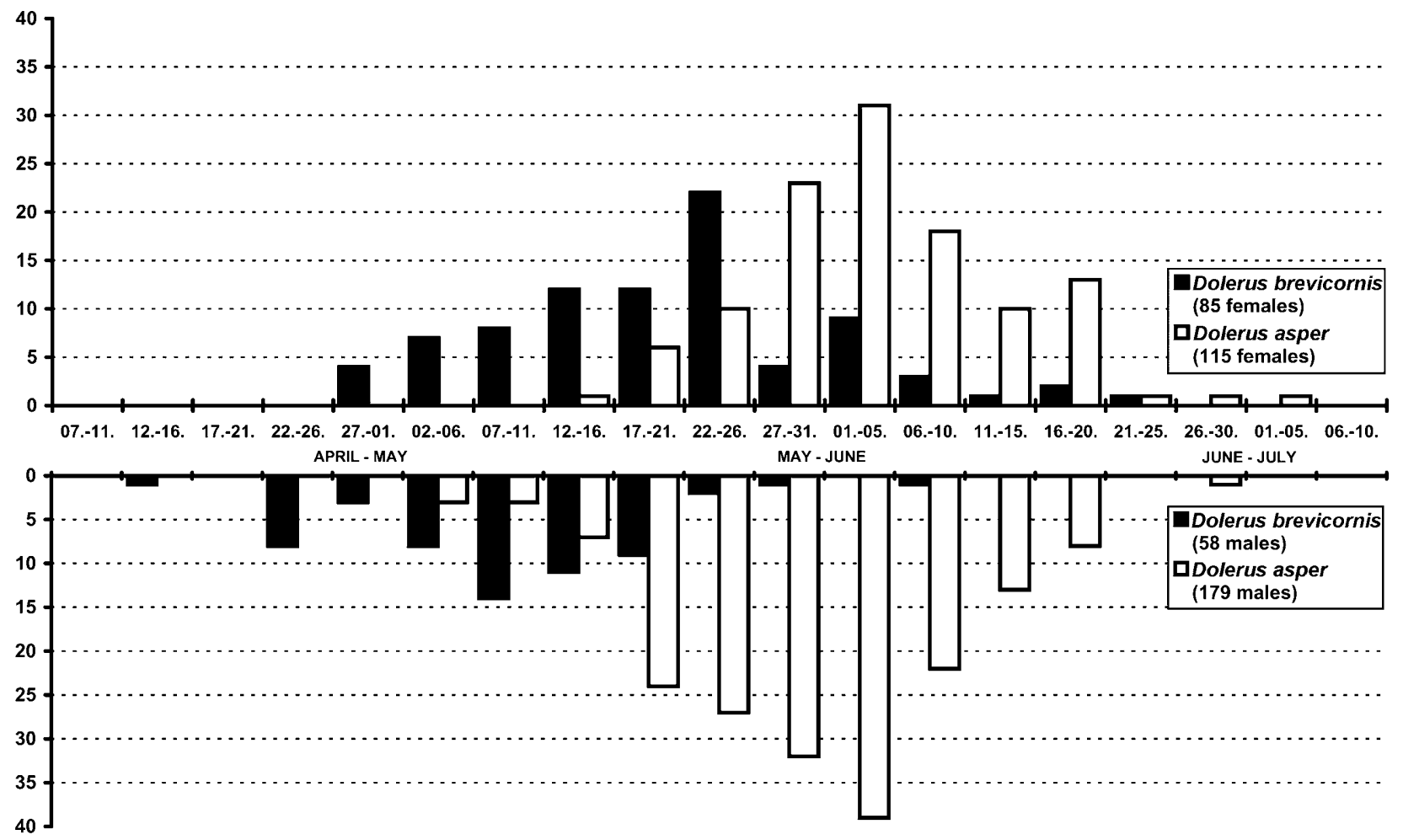

Fig. 3. Phenology diagrams for the imaginal stages of D. brevicornis Zaddach, spec. rev. and D. asper Zaddach, spec. rev. based on the numbers of adults collected in Vuohiniemi (Southern Finland) on different dates in April-July, from 1946 to 1997.

4C) differs from D. asper (Fig. 4A) and D. brevicornis (Fig. 4B), but resembles D. harwoodi. Examination of the $2+$ paratypes of Dolerus harwoodi Benson, 1947 revealed that a specimen collected from Dalby (Sweden) and identified by Benson as $D$. harwoodi is actually $D$. asper. Dolerus derzavini Malaise, 1931, described from the Russian Far East from one female (male is unknown), was later regarded as a synonym of $D$. asper by Zhelochovtsev (1935). However, the basal serrulae of lancet (Fig. 5) and the outline of mesepisternum of D. derzavini holotype in frontal view fall outside the range in variation of these characters in $D$. asper and $D$. brevicornis. Therefore, the synonymy of $D$. derzavini to $D$. asper is abandoned.

Lacourt (1999) raised Dolerus asper megapteroides Muche, 1964 to species rank. Its holotype was not found and the sex of the type specimen not mentioned in Muches's description (Muche, 1964). According to Muche (1964) the type was deposited in his collection. So far, only a female paratype in the Berlin Museum is known (S.M. Blank and J. Lacourt, pers. comm.). According to structural characters, it is conspecific to $D$. asper. Also, the metrical characters indicate that the paratype female of $D$. asper megapteroides falls in the same cluster as specimens of D. asper (Fig. 1B). Additional material from the type locality of $D$. asper megapteroides (Bolu-daglari [= Bolu mountains], Anatolia) consists of 3 (coll. M. Kraus), all of which belong to $D$. asper.

Comparison of the penis valves of $D$. asper auct. illustrated in the literature by different authors also reveals two distinct types. We suggest that the illustrations given in Goulet (1986: Fig. 170) and Benson (1952: Fig. 235, 1956: Fig. 15) for $D$. asper are indeed the penis valves of $D$. asper Zaddach, spec. rev. while those given in Zhelochovtsev (1935: Fig. 4) and Muche (1964: Fig 5) for $D$. asper are those of D. brevicornis Zaddach, spec. rev. The true identity of the Dolerus asper megapteroides penis valve given in Muche (1964: Fig. 4) remains ambiguous as long as the males collected from the Bolu mountains in Anatolia by Muche are not traced. Benson (1968) suggested that it is D. megapterus Cameron, 1881; however, it seems more likely that the penis valve figure of $D$. asper megapteroides is really that of $D$. asper, as indicated also by other characters given by Muche (1964). Of course, it cannot be excluded that the material regarded by Muche (1964) as D. asper megapteroides includes more than one species or the penis valve drawing by him (Muche, 1964: Fig 4) is imprecise and misleading. Identity of the two rather rough sketches of the penis valves drawn by Muche (1969: Figs 67-68) for $D$. asper also remains uncertain. They look very different from $D$. asper and may be D. gibbosus and D. blanki Liston, 1995, respectively. Because the setae on the mesepisternum of a female of $D$. asper illustrated in Benson (1952: Fig. 210) are very short, we regard it as D. brevicornis while the penis valve he illustrated for $D$. asper was most probably based on that of a male of $D$. asper.

\section{Identification key}

Dolerus gibbosus species group was defined on the basis of synapomorphic hooklike process of the penis valves in its members by Heidemaa \& Viitasaari (in 


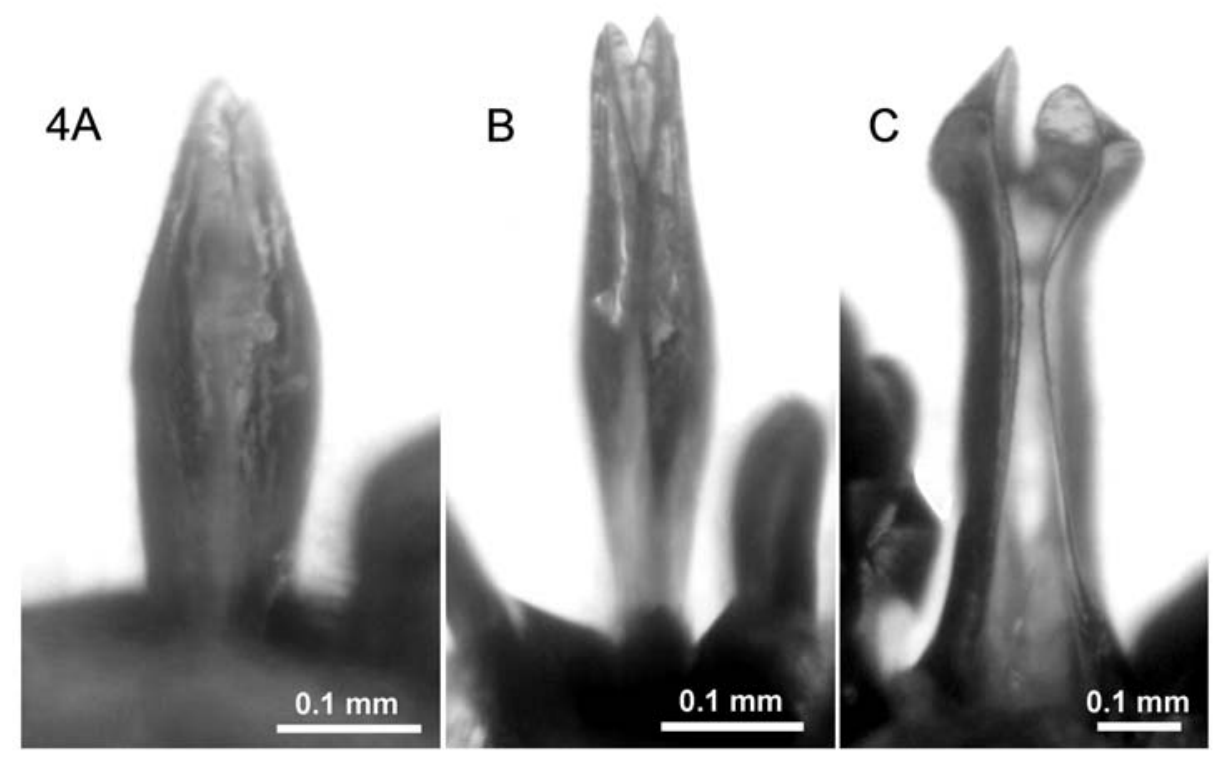

5
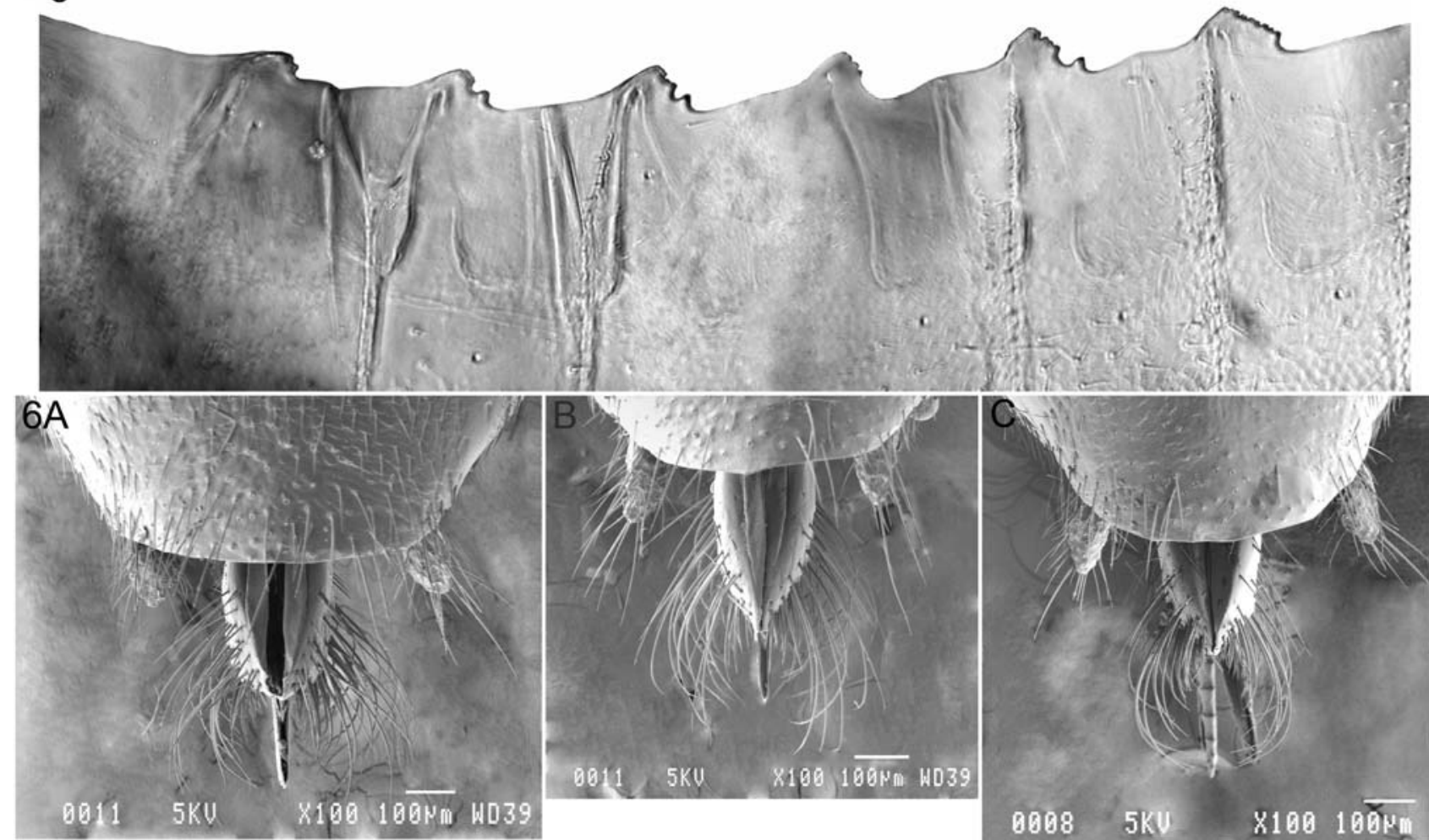

Figs 4-6. 4 - Penis valves in dorsal view. A - D. asper Zaddach, spec. rev.; B - D. brevicornis Zaddach, spec. rev.; C - D. gibbosus Hartig. 5 - Holotype of Dolerus derzavini Malaise, 1931, basal serrulae. 6 - Valvulae 3 (apical sheath) in dorsal view (SEM). A - D. asper Zaddach, spec. rev.; B - D. brevicornis Zaddach, spec. rev.; C - D. harwoodi Benson.

press). An identification key in Heidemaa \& Viitasaari (in press) also includes similar species that probably do not belong to this species group, although the females $D$. asper and D. brevicornis are not distinguished (they run to $D$. asper auct.). The following key is for the differentiation of $D$. asper Zaddach, 1859 and D. brevicornis Zaddach, 1859 from each other, and from the female of $D$. harwoodi and the male of D. gibbosus, which have often been confused with the respective sexes of the aforementioned species.

\section{Key to the imagos of $D$. asper, D. brevicornis, $D$.} harwoodi (I), and $D$. gibbosus (k)

1 Female. Body black; longest setae of valvulae 3 (apical sheath) in dorsal view curved from their base and in contour forming a longitudinal oval or circle. (Fig. 6A-C). . . . 2

- Male. Body black; ventroapical corner of the penis valve bears hooklike process (Fig. 7A-C) . . . . . . . . 6

2 Longest setae on upper part of head shorter (Fig. 8A) or at most only slightly longer than ocellus diameter (Fig. 8B); body length typically under $9.5 \mathrm{~mm} \ldots \ldots \ldots \ldots \ldots . \ldots$ 


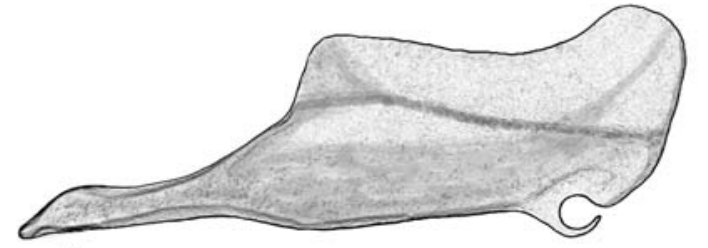

A

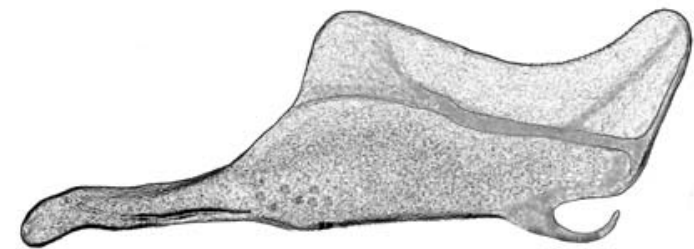

B
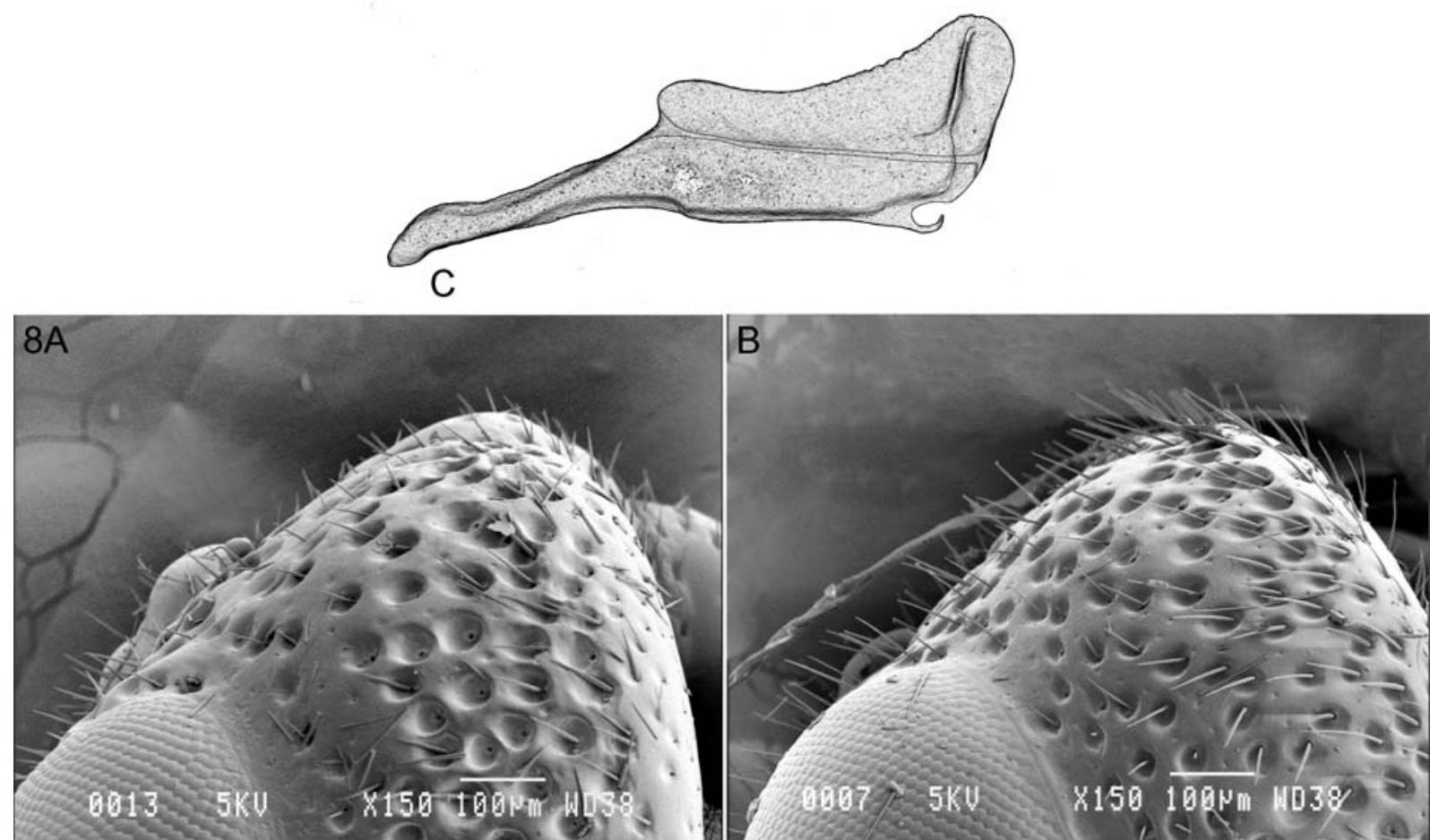

Figs 7-8. 7 - Penis valves in lateral view. A - D. asper Zaddach, spec. rev.; B - D. brevicornis Zaddach, spec. rev.; C $-D$. gibbosus Hartig (schematic). 8 - Setae on upper part of head of females (SEM). A - D. brevicornis Zaddach, spec. rev.; B - D. harwoodi Benson.

- Longest setae on upper part of head at least $1.5 \times$ longer than ocellus diameter; large species with body length typi-

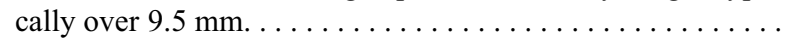
... other species (a key by Heidemaa \& Viitasaari, in press)

3 Upper halves of the lateral portions of mesepisternum in frontal view more or less parallel or slightly converging (Fig. 9A-B) with setae either uniform and shorter than ocellus diameter (Fig. 9B) or of variable length, some about as long as ocellus diameter or even longer, and some distinctly shorter (Fig. 9A); longest setae on valvulae 3 in dorsal view directed more or less backwards and form a lon-

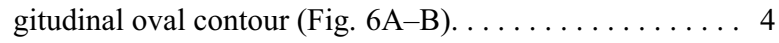

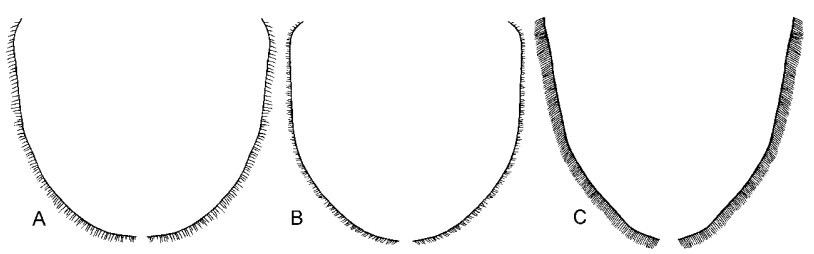

Fig. 9. Outline of the mesepisternum with setae of females (frontal view). A - D. asper Zaddach, spec. rev.; B - D. brevicornis Zaddach, spec. rev.; $\mathrm{C}-D$. harwoodi Benson (schematic).
- Upper halves of the lateral portions of mesepisternum in frontal view distinctly converging with setae dense and almost uniform, mostly longer than ocellus diameter (Fig. 9C); longest setae on valvulae 3 in dorsal view directed inwards and form a more or less circular contour (Fig. 6C). . Dolerus harwoodi Benson, 1947

4 Setae on dorsolateral edge of pronotum (half way towards tegula) about as long as ocellus diameter or longer (Fig. 10A); clypeus usually asymmetrical with emargination about $0.5 \times$ as deep as its median length (Fig. 11A); interspaces between the punctures on central part of mesepisternum more or less uniform, typically narrower than diameter of larger punctures on mesepisternum and without distinct sculpture (Fig. 12A); setae on mesepisternum of variable length, longest about as long as ocellus diameter or slightly longer and shortest about half its diameter; postocellar furrows typically obsolete; some of the longest setae of valvulae 3 in dorsal view usually directed more backwards than inwards, and form a slightly longitudinal oval contour (Fig. 6A) . . . . . . . . . . . . . . . . . . . .............. Dolerus asper Zaddach, 1859, spec. rev. Setae on dorsolateral edge of pronotum (halfway towards tegula) distinctly shorter than ocellus diameter (Fig. 10B); clypeus more or less symmetrical with emargination about $0.35 \times$ as deep as its median length (Fig. 11B); interspaces between punctures on central part of mesepisternum usually 

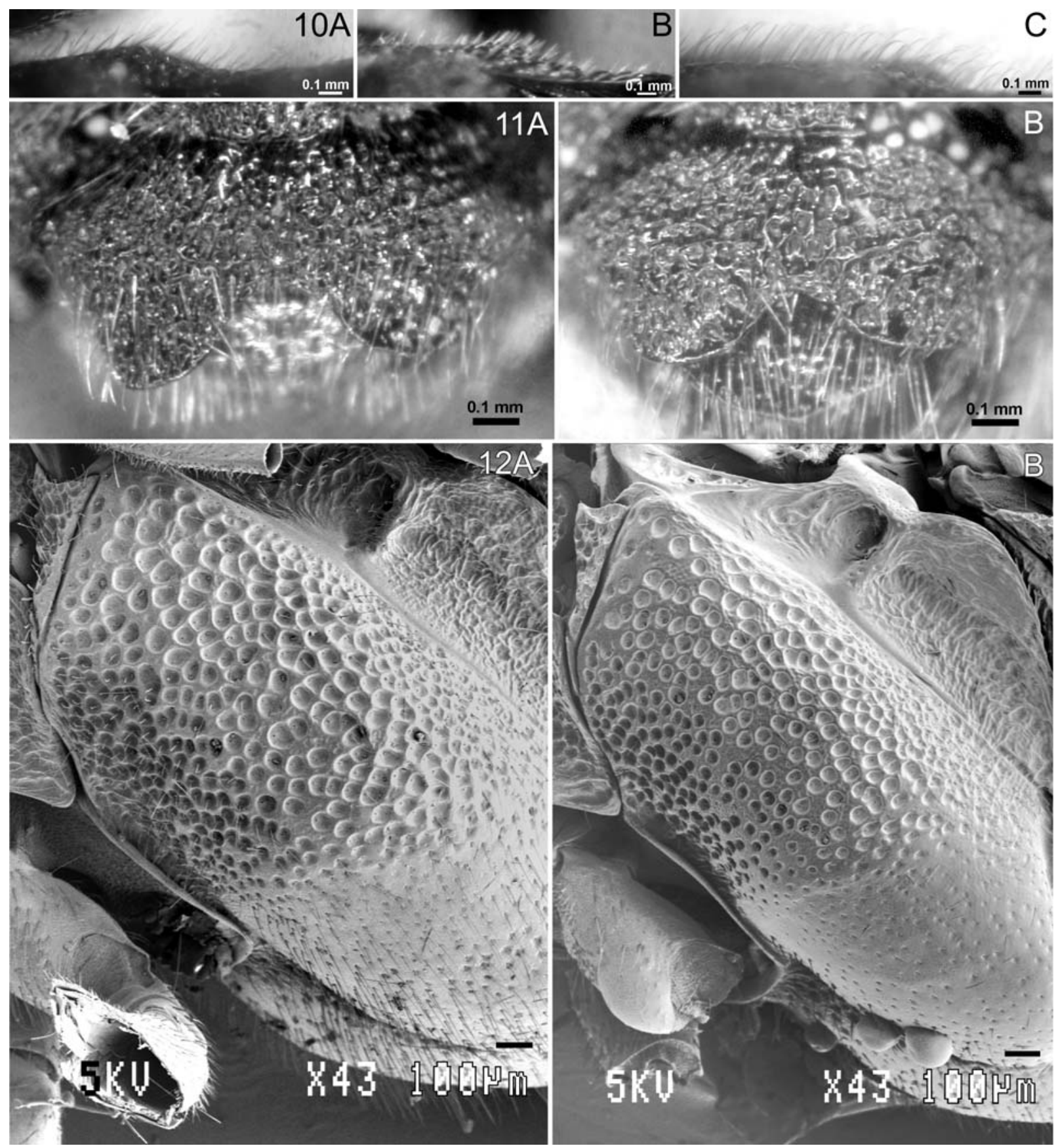

Figs 10-12. 10 - Setae on dorsolateral edge of pronotum. A - D. asper Zaddach, spec. rev.; B - D. brevicornis Zaddach, spec. rev.; C - D. gibbosus Hartig. 11 - Clypeus. A - D. asper Zaddach, spec. rev.; B - D. brevicornis Zaddach, spec. rev. 12 - Surface of the mesepisternum of females (SEM). A - D. asper Zaddach, spec. rev.; B - D. brevicornis Zaddach, spec. rev.

not uniform, at least some occupy an area comparable with larger punctures on mesepisternum, and display distinct sculpture (Fig. 12B); setae on mesepisternum sparse, usually shorter than ocellus diameter; postocellar furrows typically distinct; longest setae of valvulae 3 in dorsal view point more or less uniformly inwards and form a distinctly longitudinal oval contour (Fig. 6B).

Dolerus brevicornis Zaddach, 1859, spec. rev.

6 Penis in dorsal view gradually broadening and then narrowing (Fig. 4A-B); maximum height of apical part of the valviceps in lateral view less or little greater than its maximum basal height (Fig. 7A-B); ventroapical hooklike process well developed; tergum I more or less matt and with several punctures; clypeus emargination variable $(0.35-0.5$ $x$ its median length). . . . . . . . . . . . . . . 7 - Penis valves in dorsal view sharply broadening and then narrowing (Fig. 4C); maximum height of apical part of the valviceps in lateral view clearly exceeds its maximum basal height (Fig. 7C); ventroapical hooklike process weakly developed; tergum I glossy, without or with few punctures; clypeus emargination about $0.5 \times$ as deep as clypeal median length; penis valves in lateral view as in Fig 7C. .

Dolerus gibbosus Hartig, 1837

7 Clypeal emargination deeper, about $0.5 \times$ as deep as clypeal median length; penis valves in lateral view as in Fig 7A, tip of ventroapical hooklike process usually not reaching the 
level of distal margin of valviceps. . . . . . . . . . . . ........... Dolerus asper Zaddach, 1859, spec. rev. - Clypeal emargination shallower, about $0.35 \times$ as deep as clypeal median length; penis valves in lateral view as in Fig. $7 \mathrm{~B}$, tip of ventroapical hooklike process usually reaches the level of distal margin of valviceps. . . . . . . . . . . . ........ Dolerus brevicornis Zaddach, 1859, spec. rev.

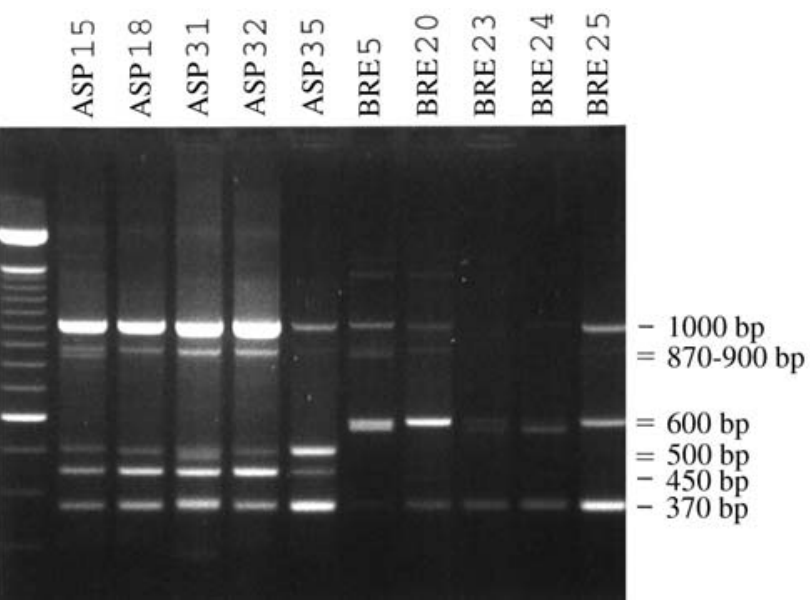

Fig. 13. RAMS patterns in specimens of $D$. asper Zaddach, spec. rev. (labelled ASP 15-ASP 35) and D. brevicornis Zaddach, spec. rev. (labelled BRE 5 - BRE 25). The RAMS markers discussed in the text are shown on the right.

\section{Dolerus asper Zaddach, 1859, spec. rev.}

Dolerus asper Zaddach, 1859: 21

Dolerus asper auct. partim.: Benson (1952: Fig. 235, 1956: Fig. 15), Goulet (1986: Fig. 170)

Dolerus oblongus Cameron, 1882: 177

Dolerus asper megapteroides Muche, 1964: 33-34; synonymy proposed by Benson (1968), ( 9 nec $ぇ$ )

Neotype. Deposited in DEI, labelled: "ESTONIA 2003, Ta: Leetsi, ME77 12.05., NL 58:24:49 EL 26:31:20, M. Heidemaa leg." [white printed label]; "Water flood of the River Emajõgi, catkins of Salix sp., sweep net" [white printed label]; "NEOTYPUS k, Dolerus asper, ZADDACH, 1859, M. Heidemaa design." [red printed label]; "Dolerus asper, Zaddach 1859, M. Heidemaa det." [white printed label].

Female. Setae on dorsolateral edge of pronotum (halfway towards tegula) about as long as ocellus diameter or longer (Fig. 10A). Clypeus usually asymmetrical with emargination about $0.5 \times$ as deep as its median length (Fig. 11A). Interspaces between punctures on central part of mesepisternum more or less uniform, usually distinctly narrower than diameter of larger punctures on mesepisternum and without distinct sculpture (Fig. 12A). Setae on mesepisternum of variable length: longest about as long as ocellus diameter or slightly longer and shortest about half of it. Postocellar furrows typically obsolete. Some of the longest setae of valvulae 3 in dorsal view usually point more backwards than inwards, and form a slightly longitudinal oval contour (Fig. 6A).

Male. Penis in dorsal view as in Fig. 4A; tip of the ventroapical hooklike process usually not reaching level of distal margin of valviceps (Fig. 7A). Lateral postocellar furrows obsolete in most cases. Clypeus usually asym-

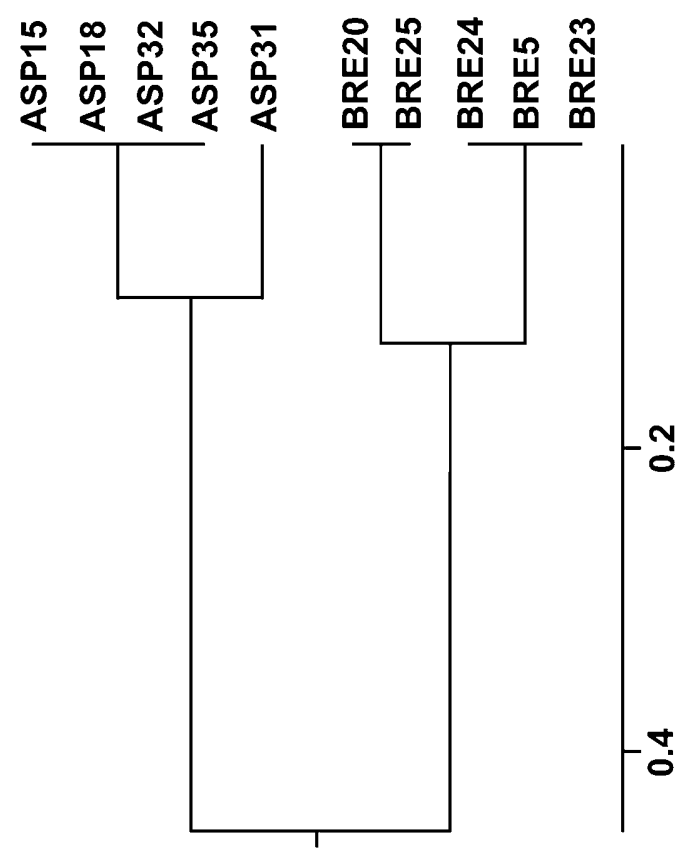

Fig. 14. Dendrogram of UPGMA clustering of RAMS markers in D. asper Zaddach, spec. rev. and D. brevicornis Zaddach, spec. rev.

metrical with emargination about $0.5 \times$ as deep as its median length (Fig. 11A).

Host. Carex acuta Bell., C. cespitosa L., C. nigra (L.) and most probably other Carex spp. Feeding success on Poaceae needs to be studied. The females also oviposited on Poa pratensis L. but the larvae died. Barker (in press) has reared larvae of this species on Carex panicea L. and Eriophorum sp. However, according to her observations many wide-leaved Carex spp. were rejected by larvae.

Distribution. Holarctic. The verified records for countries in the Palearctic are: Austria, Switzerland, Germany, Estonia, Finland, France, Latvia, Norway, Russia (European and Far East) and Sweden. Altogether over 600 specimens were examined. The northernmost records in Palearctic are from Utsjoki $\left(69^{\circ} 48^{\prime} \mathrm{N}\right)$ in Finland and from Parasdalen $\left(69^{\circ} 05^{\prime} \mathrm{N}\right)$ in Norway.

\section{Dolerus brevicornis Zaddach, 1859, spec. rev.}

Dolerus brevicornis Zaddach, 1859: 25

Dolerus asper auct. partim.: Benson (1952: Fig. 210), Muche (1964: Fig. 5), Zhelochovtsev (1935: Fig. 4)

? Dolerus tectus MacGillivray, 1914: 104 (holotype female, not examined).

Neotype. Deposited in DEI, labelled: "ESTONIA 2003, Ta: Laane, ME86 12.05.03, NL 58:19:14 EL 26:40:48, M. Heidemaa leg." [white printed label]; "drain, Carex spp. sweep net" [white printed label]; "NEOTYPUS k, Dolerus brevicornis, ZADDACH, 1859, M. Heidemaa design." [red printed label]; “Dolerus brevicornis, Zaddach 1859, M. Heidemaa det." [white printed label].

Female. Setae on dorsolateral edge of pronotum (halfway towards tegula) distinctly shorter than ocellus diameter (Fig. 10B); clypeus more or less symmetrical with emargination about $0.35 \times$ as deep as its median length (Fig. 11B); interspaces between punctures on cen- 

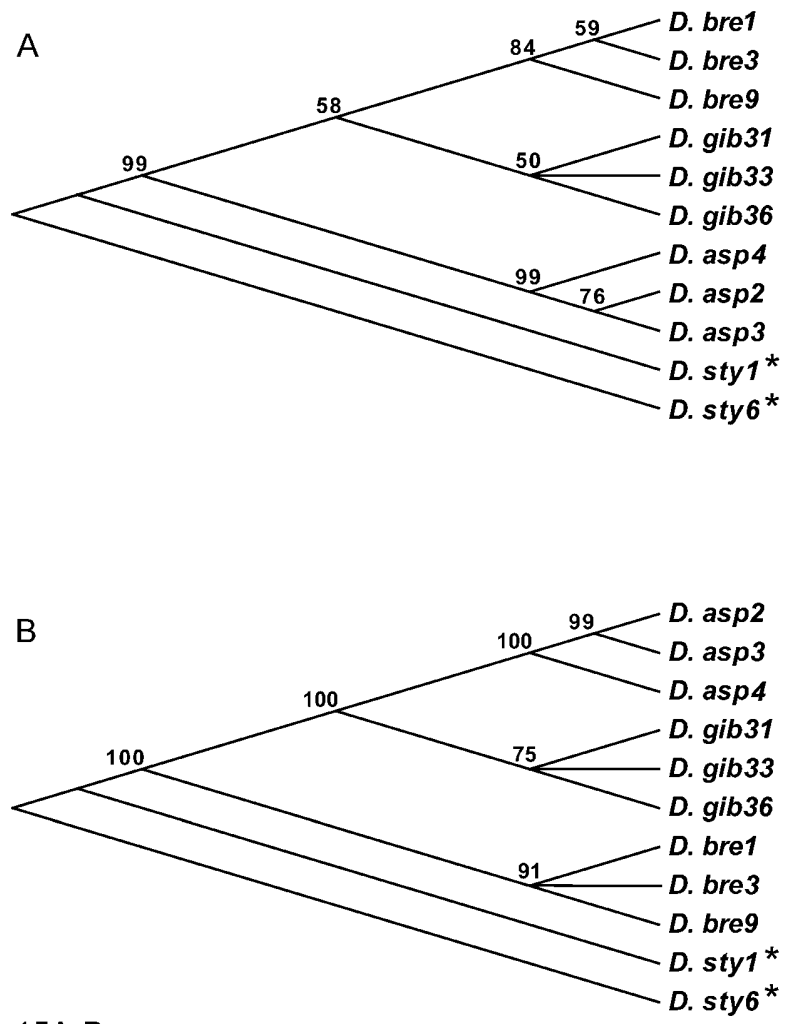

$15 \mathrm{~A}-\mathrm{B}$

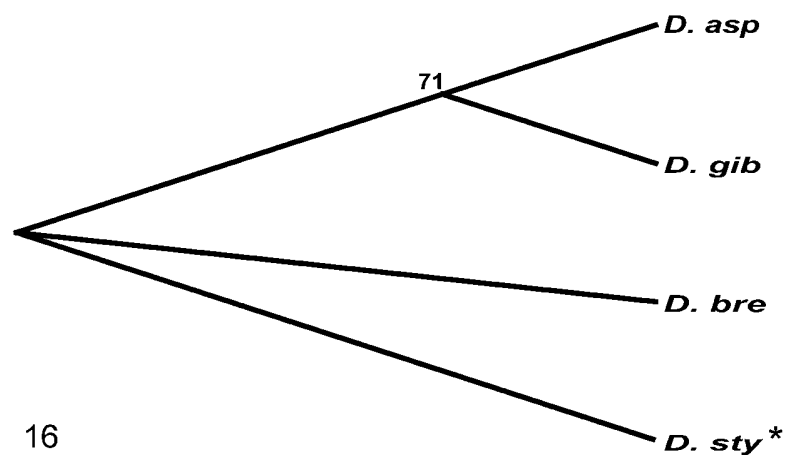

Figs 15-16. 15 - Tree topologies for D. asper Zaddach, spec. rev. (D. asp), D. brevicornis Zaddach, spec. rev. (D. bre) and $D$. gibbosus Hartig (D. gib) estimated from unweighted parsimony analysis conducted in PAUP* using exhaustive search. Numbers above the branches indicate bootstrap support from 10,000 pseudoreplicates. A - consensus (cut-off value $=50 \%$ ) based on the 8 most parsimonious cladograms resulting from the combined sequences of COII (356 bp) and ITS2 (479 bp) fragments. $\mathrm{B}-$ consensus tree, with $75 \%$ cut-off value, based on the 3 most parsimonious cladograms resulting from the combination of all analysed markers: cytb (517 bp) + COI (272 bp) + COII (356 bp) + ITS2 (479 bp). 16 - Single most parsimonious cladogram resulting from an unweighted parsimony analysis of 3 imaginal characters of $D$. asper Zaddach, spec. rev. (D. asp), D. brevicornis Zaddach, spec. rev. (D. bre) and D. gibbosus Hartig (D. gib), conducted in PAUP* using exhaustive search. D. stygius Förster was used as an outgroup. Number between branches indicates bootstrap support from 10,000 pseudoreplicates, ${ }^{*}-$ outgroup. tral part of mesepisternum usually not uniform, at least some occupy an area comparable to the larger punctures on mesepisternum, and have a distinct surface sculpture (Fig. 12B); typically most setae shorter than ocellus diameter. Postocellar furrows typically distinct. Longest setae of valvulae 3 in dorsal view point more or less uniformly inwards forming a distinctly longitudinal oval contour (Fig. 6B).

Male. Penis in dorsal view as in Fig. 4B; tip of ventroapical hooklike process usually reaches level of distal margin of valviceps (Fig. 7B). Lateral postocellar furrows distinct in most cases. Clypeal emargination about $0.35 \times$ as deep as clypeal median length (Fig. 11B).

Host. Carex cespitosa and some other Carex spp., e.g. C. nigra (T. Kontuniemi, unpubl.).

Distribution. Probably Holarctic, as the Nearctic records are unverified. The verified records for countries in the Palearctic are: Austria, Germany, Estonia, Finland, France, Norway, Russia (European and Far East) and Sweden. Altogether about 600 specimens were examined. The northernmost records are from Ivalo $\left(68^{\circ} 38^{\prime} \mathrm{N}\right)$ and Kittilä $(\mathrm{KemL})$ in Finland, and Petsamo in Russian Karelia.

\section{Differentiation of $D$. asper and $D$. brevicornis using RAMS markers}

Since some females of $D$. asper and D. brevicornis could not be differentiated morphologically, RAMS markers were used for discrimination. Using the primer $\mathrm{DHB}(\mathrm{CGA})_{5}$ 4-6 amplification products were obtained from $D$. asper and 4-8 from D. brevicornis (Fig. 13). A marker with a size of $450 \mathrm{bp}$ was present in all specimens of $D$. asper but not in those of $D$. brevicornis. In addition, in the specimens of $D$. asper but not $D$. brevicornis, one or two markers with a molecular weight of about $500 \mathrm{bp}$ were present. Markers with a molecular weight of about 600 bp were observed only in $D$. brevicornis. The occurrence of one or two markers within these weight ranges could be due to the length polymorphism of the markers, although this was not confirmed. The markers of $370 \mathrm{bp}$ and $1000 \mathrm{bp}$ are monomorphic, and shared by both species. The markers in the molecular weight range of 870-900 bp did not differentiate the species, although some variation was observed.

The clearly interpretable markers (1000 bp, $600 \mathrm{bp}, 580$ bp, $500 \mathrm{bp}, 480 \mathrm{bp}, 450 \mathrm{bp}$ and $370 \mathrm{bp}$ ) were used to construct an UPGMA dendrogram (Fig. 14). Segregation of the specimens of $D$. asper and D. brevicornis into two clusters was clear, and both major clusters were formed from two subclusters. In this connection it should be noted that the $D$. asper individuals originated from Finland and Norway, but their origin was not reflected in the UPGMA clustering as the Finnish individual was identical to the four specimens collected from Norway. Thus, the RAMS markers with molecular weights of 450,500 and $600 \mathrm{bp}$ can be used to differentiate the females of $D$. asper and $D$. brevicornis, which are morphologically inseparable. This suggests that Dolerus asper auct. includes two distinct species. Furthermore, some of the RAMS markers could be used to study the intraspecific variation in these species. 
TABLE 1. Variable sites in the gene fragments of D. brevicornis Zaddach (D.bre), D. asper Zaddach (D.asp), D. gibbosus Hartig (D.gib) and D. stygius Förster (D.sty). In brackets after a marker the number of variable and parsimony informative sites (in total $76 / 68$, respectively) is indicated. POS - nucleotide position in the dataset.

\begin{tabular}{|c|c|c|c|c|c|}
\hline & MARKER & cytb $(17 / 15)$ & $\operatorname{COI}(7 / 6)$ & COII $(7 / 7)$ & ITS $(45 / 40)$ \\
\hline & \multicolumn{3}{|l|}{$\mathrm{P}$} & 111 & 111111111111111111111111111111111111111111111 \\
\hline & \multirow{3}{*}{$\begin{array}{l}\mathrm{O} \\
\mathrm{S}:\end{array}$} & 111122334444 & 5667777 & 8889001 & 122222344444444444444444444445555555555556666 \\
\hline & & 2490155733782599 & 2040128 & 1993230 & 711278301233333556667777788990002334456680122 \\
\hline & & 56021328013773267 & 5680113 & 5673326 & 167420667634789583580123445281493582486815713 \\
\hline \multirow{11}{*}{$\begin{array}{l}\text { Species } \\
\text { sample: }\end{array}$} & D.brel & AGACTATTAGTTAGTTC & СAATACT & TGACCTA & CACCGGGCGGTCGCGCAAGGACGTCCCGTCAGTCAACCTTCTGGA \\
\hline & D. bre 3 & $\ldots \mathrm{T} \ldots \ldots \ldots \ldots$ & $\ldots \ldots$ & $\ldots \ldots$ & $\ldots \ldots$ т. $\ldots \ldots \ldots \ldots \ldots \ldots \ldots$ \\
\hline & D.bre9 & $\ldots \mathrm{T} \ldots \ldots \ldots \ldots$ & $\ldots \ldots$ & $\ldots \ldots$ & $\ldots \ldots$. $\ldots \ldots \ldots \ldots \ldots \ldots$ А. . . \\
\hline & D. $\operatorname{asp} 2$ & .ATT.TC.T.A.GAACT & TT ... TC & . CTTCG & $\ldots$ A.A.A.AA. A...GG . . . . A. . . . G.C.TACTCAAG \\
\hline & D. $\operatorname{asp} 3$ & TATTCT.CTA. .GAACT & T.GG.T. & . СТTCG & 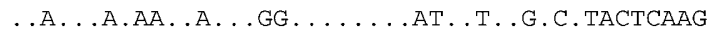 \\
\hline & D. asp4 & TATT.T.CTA. .GAACT & T..G.TC & . СTTCG & 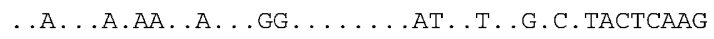 \\
\hline & D.gib31 & TATT.TC.T.A.GAACT & TT...TC & . ACTTCG & 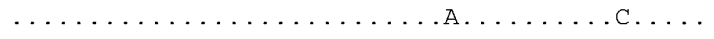 \\
\hline & D.gib33 & TATT. TC.T.A.GAACT & TT . . TC & . ACTTCG & 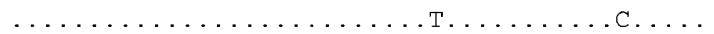 \\
\hline & D.gib36 & TATT.TC.T.A.GAACT & TT . . TC & . АСТTCG & $\ldots$ А. . \\
\hline & D. styl & $\ldots$ T....А. .. Т & $\ldots$ т. & G. T... & AT...AA. AGT.T.G. CACGTCAT.T. .AC.GCA ..... A. \\
\hline & D.sty 6 & $\ldots$ Т...А.А...Т & $\ldots \mathrm{T} \ldots$ & G. T... & A....AA. .AGT.TAG. CACGTCAT.T.G.AC.GCA . C. .A. \\
\hline
\end{tabular}

\section{Phylogenetic analysis}

Phylogenetic relationships between the species were estimated from the sequences of mitochondrial and nuclear DNA fragments (Fig. 15A-B) as well as from the structural characters of the adults (Fig. 16). Dolerus docilus, probably a very closely related species to $D$. asper, was excluded from the study because suitable material for molecular analysis was unavailable.

\section{Molecular data}

Fragments of the mtDNA genes (cytb, COI and COII) and of nuclear DNA (ITS2) from 3 specimens of each species were PCR-amplified and both strands sequenced. Sequences were aligned, trimmed, and the resulting sequences with $517 \mathrm{bp}$ of cytb, $272 \mathrm{bp}$ of COI, $356 \mathrm{bp}$ of COII and 479 bp of ITS2 were used for making phylogenetic inferences. The number of variable and parsimony informative sites of the analysed gene fragments is as follows: 17 and 15 for $c y t b, 7$ and 6 for COI, 7 and 7 for COII, and 45 and 40 for ITS2, respectively (Table 1). Altogether 76 variable and 68 parsimony informative

TABLE 2. Data matrix of 6 morphological characters imaginal scored for the four species. Characters 1, 2 and 4 are parsimony informative while 3,5 and 6 are not. All characters except 5 (Wagner character) are treated as unordered. * - outgroup.

\begin{tabular}{|c|c|}
\hline Species / Characters & 1.2.3.4.5.6. \\
\hline D. asper (D.asp) & $\begin{array}{llllll}1 & 1 & 0 & 1 & 1 & 1\end{array}$ \\
\hline D. brevicornis (D.bre) & $\begin{array}{lllllll}0 & 0 & 1 & 1 & 1 & 0\end{array}$ \\
\hline D. gibbosus (D.gib) & $\begin{array}{llllll}1 & 1 & 0 & 0 & 2 & 0\end{array}$ \\
\hline D. stygius (D.sty) & $\begin{array}{llllll}0 & 0 & 0 & 0 & 0 & 0\end{array}$ \\
\hline
\end{tabular}

1. Clypeus outline: symmetric $=0$; asymmetric $=1$.

2. Clypeal emargination compared to median length of clypeus: shallow (about 0.35$)=0$; deep $($ about 0.5$)=1$.

3. Setae on upper part of head: long $=0$; short $=1$.

4. Ventroapical hooklike process of penis valve: small $=0$; large $=1$

5. Apex of penis in dorsal view: uniform $=0$; gradually broadening $=1$; sharply broadening $=2$.

6. Postocellar furrows in males: distinct $=0$; obsolete $=1$. sites were found. The consensus trees from unweighted MP analyses of ITS2 alone and combinations of COI + ITS2 and COII + ITS2 have the topology $[D$. asper, $(D$. brevicornis, D. gibbosus)]. The consensus tree of the 12 most parsimonious trees with length 61 is given in Fig 15A. The same topology resulted if the ME criterion was used and both transitions and transversions were included. However, the topology $[D$. brevicornis, $(D$. asper, D. gibbosus)] emerged from the ME analysis of COI + ITS2 and COII + ITS2 if only transitions were considered. Furthermore, all consensus trees inferred from unweighted MP and NJ analyses of all other possible combinations of the sequenced markers had topology $[D$. brevicornis, $(D$. asper, D. gibbosus $)]$. The MP analysis based on all four markers combined (1624 bp) yielded three most parsimonious trees with length 91 . The resulting consensus tree, with $75 \%$ cut-off value and bootstrap support values indicated, is given in Fig. 15B. Briefly, the phylogenetic analyses using most markers and their combinations resulted in the topology $[D$. brevicornis, (D. asper, D. gibbosus)], with very high bootstrap support for the clade $D$. asper $+D$. gibbosus (see Fig. 15B), while only a few resulted in the topology $[D$. asper, (D. brevicornis, D. gibbosus)]. In the latter, the clade brevicornis + gibbosus had low bootstrap support (see Fig. 15A).

\section{Morphological data}

In this study, only imagos were used as their larval stages are insufficiently known. Of the 6 variable structural characters, three were parsimony informative and three uninformative (Table 2). An unweighted MP analysis of the morphological dataset gave a single most parsimonious tree of 8 steps (Fig. 16). The clade asper + gibbosus with bootstrap support 71 is supported by two synapomorphies: asymmetric clypeus and clypeal emargination about $0.5 \times$ as deep as its median height. We found no morphological synapomorphies for the clade asper + brevicornis + gibbosus, which gained very high bootstrap support (99-100) from the phylogenetic analyses of molecular data (see Fig. 15A-B). 


\section{Notes on phenology, host plant and distribution}

The phenology diagrams (Fig. 3) for the adults of $D$. asper and D. brevicornis are based on 200 female and 237 male specimens captured by MN and J. Nuorteva in Vuohiniemi, Southern Finland $\left(60^{\circ} 57^{\prime} \mathrm{N}, 2^{\circ} 04^{\prime} \mathrm{E}\right)$ from April to July during 1946-1997. In comparison with $D$. asper the flight of $D$. brevicornis begins and ends earlier.

For both species (D. asper and D. brevicornis) one male was reared from a larva collected on Carex nigra (L.) by T. Kontuniemi in 1949 and included in his material of $D$. asper (currently in the coll. M. Viitasaari) but not reported in Kontuniemi (1960). The ex ovo rearing of the species was successfully carried out on Carex cespitosa and C. nigra by MH in 2002-03. O. Conde described and reared the larvae of $D$. carbonarius Zaddach on Deschampsia, Poa and Carex stricta or C. cespitosa, and D. oblongus Cameron on Carex sp. (Conde, 1933). We have not studied the material reared by Conde, and its taxonomic composition is unknown to us.

Dolerus asper and D. brevicornis are common in the Palearctic Region. The current distribution of the less common D. gibbosus seems incomplete, but differs in its distribution compared with the two former species, as it occurs in Estonia and is absent from Finland (Viitasaari et al., 1998). Based on collections, it seems that D. asper is more common in Lapland than $D$. brevicornis. There are numerous records of $D$. asper from Finland north of the Polar Circle (the biological provinces: KemL, EnL and InL) and similarly for Norway and Russia, but for $D$. brevicornis there are three such records. We have not studied the Nearctic material of $D$. asper and the holotype female of Dolerus tectus MacGillivray, 1914, but the illustration of the penis valve of $D$. asper in Goulet (1986: Fig. 170a) indicates that $D$. asper occurs in the Nearctic. Also, the outline of the mesepisternum with short setae in Goulet (1986: Fig. 30) suggests that $D$. brevicornis should be present in the Nearctic. A study of the North American specimens is required to confirm the occurrence of $D$. brevicornis in the Nearctic Region.

ACKNOWLEDGEMENTS. A. Albrecht (FMNH), S.M. Blank (DEI, ZALF), E. Diller (ZSM), L.O. Hansen (ZMUO), L.-Å. Janzon (NHRM), A. Karpa (IBUL), S. Lewis (BMNH), J. Luig (MZUT), A. Nielsen (ZDTM), S. Schödl (NHMV), A. Taeger (DEI, ZALF), C. Taylor (BMNH), and A. Zinovjev (ZISP) lent us material and type specimens from their institutional collections. S.M. Blank, K. Elberg (Tartu, Estonia), M. Kraus (Nürnberg, Germany), J. Lacourt (Le Pâty, Igé, France), J. Nuorteva (Helsinki, Finland), A. Taeger, M. Viitasaari (DABUH) and V. Vikberg (Turenki, Finland) let us study material from their private collections. F. Pesarini (Museo Civico di Storia Naturale, Ferrara, Italy) donated some specimens of Dolerus docilus. I. Luovula (Finnish Forest Research Institute) skilfully assisted in the RAMS analysis. T. Nyman (University of Joensuu, Finland) helped to select the primers for the amplification of the mtDNA markers. M. Viitasaari and S. Lehtinen (Microfocus OY) arranged the SEM sessions. M. Koponen (DABUH) helped us to borrow the type specimens from the BNHM. A. Taeger and S.M. Blank commented on the manuscript. D.R. Smith reviewed the text and gave several helpful suggestions. Centre for International Mobility (Helsinki, Finland) and the staff of the Dept. of
Applied Biology made it possible for $\mathrm{MH}$ to come to Finland to carry out cooperative research in the University of Helsinki. G. Grishanov (Dept. of Zoology and Ecology, Kaliningrad State University) and A. Utevsky (Dept. of Zoology and Animal Ecology, Kharkov State University) replied to our requests concerning the hymenoptera collections of G. Zaddach and G. Brischke. J. Lind (Estonian Biocentre, Tartu) helped in DNA sequencing. Two anonymous reviewers provided constructive comments and suggestions. We extended our cordial thanks to all of them.

\section{REFERENCES}

BARKER A.M. (in press): Further descriptions of Dolerus larvae, with notes on larval identification and feeding habits. In Smith S., Taeger A. \& Blank S.M. (eds): Recent Sawfly Research: Synthesis and Prospects. Goecke \& Evers, Keltern.

Benson R.B. 1947: Two new European species of Dolerus Jurine (Hym., Tenthredinidae). Entomol. Mon. Mag. 83: 62-64.

Benson R.B. 1952: Hymenoptera 2. Symphyta. Handbooks for the Identification of British Insects. Vol. 6, Part 2(b). Royal Entomological Society of London, London, pp. 51-137.

Benson R.B. 1956: Studies in Dolerini. Proc. R. Entomol. Soc. Lond. 25: 55-63.

Benson R.B. 1968: Hymenoptera from Turkey Symphyta. Bull. Br. Mus. Nat. Hist. (Entomol.) 22(4): 111-207.

Blank S.M. \& Taeger A. 1992: Die von Th. Hartig und A. Förster in der Gattung Dolerus beschriebenen Arten (Hymenoptera, Tenthredinidae). Entomofauna 13(12): 213-232.

Blank S.M. \& TAEger A. 1998: Comments on the taxonomy of Symphyta (Hymenoptera). Preliminary studies for a catalogue of Symphyta, part 4. In Taeger A. \& Blank S.M. (eds): Pflanzenwespen Deutschlands (Hymenoptera, Symphyta). Kommentierte Bestandsaufnahme. Goecke \& Evers, Keltern, pp. 141-174.

CAmeron P. 1881: Notes on Hymenoptera, with descriptions of new species. Trans. Entomol. Soc. Lond. [1881](4): 555-577.

Cameron P. 1882: A Monograph of the British Phytophagous Hymenoptera (Tenthredo, Sirex and Cynips, Linné) 1. Ray Soc., London, 317 pp.

CONDE O. 1933: Die Entwicklungsgeschichte von 15 Arten aus der Gattung Dolerus Panz. und eine systematische Zusammenstellung der Larven (Hym., Tenthr.). Notul. Entomol. 13: $19-35$.

Förster A. 1860. Eine Centurie neuer Hymenopteren. Verh. Naturh. Ver. Preuss. Rheinl. 17: 93-153.

Goulet H. 1986: The genera and species of the Nearctic Dolerini (Symphyta, Tenthredinidae, Selandriinae): Classification and phylogeny. Mem. Entomol. Soc. Can. 135: 1-208.

Hall T.A. 1999: BioEdit: a user-friendly biological sequence alignment editor and analysis program for Windows 95/98/NT. Nucl. Acids. Symp. Ser. 41: 95-98.

Hantula J., Dusabenyagasani M. \& Hamelin R.C. 1996: Random amplified microsatellites (RAMS) - a novel method for characterizing genetic variation within fungi. Eur. J. Forest Pathol. 26: 159-166.

HaRTIG T. 1837: Die Aderflügler Deutschlands mit besonderer Berücksichtigung ihres Larvenzustandes und ihres Wirkens in Wäldern und Gärten für Entomologen, Wald- und Gartenbesitzer. Die Familien der Blattwespen und Holzwespen nebst einer allgemeinen Einleitung zur Naturgeschichte der Hymenopteren. Berlin, $416 \mathrm{pp}$.

HeidemaA M. \& VittasaARi M. (in press): Taxonomy of the Dolerus gibbosus species group with descriptions of Dolerus zhelochovtsevi sp. nov., the males of D. blanki Liston, 1995 and 
D. quadrinotatus Biró, 1884, and redescription of the D. gibbosus Hartig, 1837 male (Hymenoptera: Tenthredinidae). Zootaxa.

Horn W., Kahle I., Friese G. \& Gaedike R. 1990: Collectiones entomologicae. Ein Kompendium über den Verleib entomologischer Sammlungen. Akademie der Landwirtschaftswissenschaften der DDR, Berlin, 573 pp.

KIRBY W.F. 1882: List of Hymenoptera with Descriptions and Figures of the Typical Specimens in the British Museum. 1. Tenthredinidae and Siricidae XXXVIII. Taylor \& Francis, London, 450 pp. +15 pls.

Kontuniemi T. 1960: Die Futterpflanzen der Sägewespenlarven Finnlands. Anim. Fenn. 9: 1-104.

Kumar S., Tamura K. \& Nei M. 1993: MEGA: Molecular Evolutionary Genetics Analysis. Version 1.01. The Pennsylvania State University, University Park, PA 16802.

Kumar S., Tamura K., Jakobsen I.B. \& Nei M. 2001: MEGA2: Molecular evolutionary genetics analysis software. Bioinformatics 17: 1244-1245.

LACOURT J. 1999: Répertoire des Tenthredinidae ouestpaléarctiques (Hymenoptera, Symphyta). Mémoires de la $S E F$, Vol. 3. Soc. Entomol. de France, Paris, 432 pp.

Liston A. 1995. Compendium of European Sawflies. Chalastos Forestry, Gottfrieding, $190 \mathrm{pp}$.

LYNCH M. 1990: The similarity index and DNA fingerprinting. Mol. Biol. Evol. 7: 478-484.

MacGillivray A.D. 1914: New genera and species of Tenthredinidae. Can. Entomol. 46: 103-108.

MaLAISE R. 1931: Entomologische Ergebnisse der schwedischen Kamtchatka-Expedition 1920-1922. Ark. Zoologi (A) 23(8): $1-68$.

Marinucci M., Romi R., Mancini P., Di Luca M. \& Severini C. 1999: Phylogenetic relationships of seven palaearctic members of the maculipennis complex inferred from ITS2 sequence analysis. Insect Mol. Biol. 8: 469-480.

Muche H.W. 1964: Dolerus asper megapteroides nov. ssp. (Hymenoptera, Symphyta). Reichenbachia 4(6): 31-33.

MuchE W.H. 1969: Die Blattwespen Deutschlands II. Selandrinae (Hymenoptera). Entomol. Abh. Staat. Mus. Tierk. Dresden (Suppl. 2) 36: 61-96.
Simon C., Frati F., Beckenbach A., Crespi B., Liu H. \& Flook P. 1994: Evolution, weighting, and phylogenetic utility of conserved polymerase chain reaction primers. Ann. Entomol. Soc. Am. 87: 651-701.

StatSoft, Inc. 2001: STATISTICA (Data Analysis Software System), Version 6. www.statsoft.com.

Swofford D.L. 1998: PAUP*, Phylogenetic Analysis Using Parsimony (*and Other Methods), Version 4. Sinauer Associates, Sunderland, Massachusetts.

Vainio E.J., Korhonen K. \& Hantula J. 1997: Genetic variation in Phlebiopsis gigantea as detected with random amplified microsatellite (RAMS) markers. Mycol. Res. 102: 187-192.

Vittasaari M., Heidemaa M., Nuorteva M. \& Zinovjev A. 1998: An annotated checklist of the sawflies (Hymenoptera, Symphyta) of Estonia. Proc. Eston. Acad. Sci. (Biol. Ecol.) 47(2): 126-147.

VitTASAARI M. (Ed.) 2002: Sawflies I. A Review of the Suborder, the Western Palaearctic Taxa of Xyeloidea and Pamphilioidea. Tremex Press, Helsinki, 516 pp.

ZADDACH G. 1859: Beschreibung neuer oder wenig bekannter Blattwespen aus dem Gebiete der preussischen Fauna. In: Zur öffentlichen Prüfung der Schüler des Köninglichen Friedrichs-Collegiums. Schultzsche Hofbuchdruckerei, Königsberg, pp. 3-40, 1 pl.

Zhelochovtsev A.N. 1935: Notes sur les Dolerinae (Hym.) Paléarctiques. Arch. Mus. Zool. Univ. Moscou 2: 79-84.

Zhelochovtsev A.N. 1988: [Suborder Symphyta (Chalastogastra)]. In Medvedjev G.S.: [Keys to the Insects of the European Part of the USSR. Vol. III, Hymenoptera, Part 6]. Nauka, Leningrad, pp. 7-234 (in Russian). English translation: Zhelochovtsev A.N. 1994: Suborder Symphyta (Chalastogastra). In Medvedjev G.S.: Keys to the Insects of the European Part of the USSR. 3(6). Amerind. Publ. Co. Pvt. Ltd., New Delhi, pp. 1-387.

ZietKiewicz E., Rafalski A. \& Labuda D. 1994: Genome fingerprinting by simple sequence repeat (SSR) - anchored polymerase chain reaction amplification. Genomics 20: 176-183.

Received October 20, 2003; revised February 12, 2004; accepted May 21, 2004 